\title{
Making space for experiences
}

Received (in revised form): 31 July 2006

\section{Michael Morgan}

is senior lecturer in services marketing in the School of Services Management, Bournemouth University, UK.

\begin{abstract}
Leisure and retail providers need to understand the elements of the visitor experience and the way in which they evaluate their satisfaction. This article suggests a holistic prism model of the interaction between the management and the visitor in a leisure space. This is applied to a netnographic study of visitors to a folk festival to illustrate the interconnectiveness of the different attributes causing dissatisfaction. It found that the physical and operational attributes were evaluated not through a checklist of individual features but as hindrances to the visitor's desire to make best use of the time. Visitors also evaluated the experience in the light of their own values and concerns, passing judgement on the values communicated by the management. At the heart of the experience was the enjoyment of choosing from an abundant offer and discovering something new. The main attraction is often only the pretext for enjoying the company of friends so places to meet before and chill-out afterwards are vital to the experience. The distinctiveness of the setting, the food and drink can become the sensory cues which give the event or location its uniqueness. The challenge to retail and leisure organisations is to design these elements of a memorable experience into their offerings.
\end{abstract}

\section{Keywords:}

experience economy, visitor experience, leisure and festival spaces, leisure shopping, netnography

Journal of Retail and Leisure Property (2006) 5, 305-313. doi:10.1057/palgrave.rlp.5100034

Michael Morgan

School of Services Management Bournemouth University

Talbot Campus

Fern Barrow

Poole

Dorset $\mathrm{BH}_{12} 5 \mathrm{BB}$ UK

Tel: +44 (o) 1202965174

E-mail: mmorgan@bournemouth. ac.uk

\section{INTRODUCTION}

The word 'experience' is widely used in leisure, retail and other services sectors to describe the essence of what customers are seeking and paying for. According to writers such as Pine and Gilmore it is memorable experiences rather than product- or service-quality that create sustainable competitive advantage. ${ }^{1}$ Until recently, service quality management has been seen as a way of differentiating a company's offering when there is little difference between the tangible product elements. As all competitors in an industry come to adopt this view and implement systems of quality assurance, however, service quality too becomes expected and ceases to 
create competitive advantage. Indeed, when service quality is taken for granted, services can become commoditised, bought and sold on price alone. An example of this is the way airline seats and hotel beds are booked over the internet using search engines that select the cheapest alternative for a given route and date. Independent holidays have now exceeded inclusive packages according to recent International Passenger Survey data and the future of the retail travel agent is in question. ${ }^{2}$ Books, music and even film retailing are now subject to the same pressures from on-line competitors such as Amazon.

According to Pine and Gilmore the way to retain competitive advantage for a brand is to turn a service into an experience. An experience occurs when the service is performed in a unique, memorable way which involves the customer as a participant. They produce figures to show that experience-staging companies - those charging admissions to theme parks, cinemas etc-grew faster than goods or services in terms of price, employment and share of GDP. ${ }^{1}$ As a recent paper in this journal noted, the retail sector has recognised the importance of shopping as a leisure activity, and 'the attractions of retail theatre and the blending of retail and leisure in one location'. ${ }^{3}$ Councils and city-centre managers are turning to special events to attract visitors and create a more memorable positioning for their areas.

The creation of these 'unique and memorable experiences' is achieved through dramatising the service encounter, ${ }^{1,4}$ appealing to all the senses ${ }^{5}$ telling stories about the brand ${ }^{6}$ — in other words employing a Disney-like blend of imaginative and technological approaches that $\mathrm{Nijs}^{7}$ calls Imagineering. To be truly effective, however, the experience should be more than a transitory one, offering the prospect of 'transformation' through the acquiring of new skills and knowledge or enhanced selfconfidence and self-image.

What these insights into the future of services marketing have in common is:

- a shift of emphasis from the rational to the emotional aspects of consumer decision making;

- a transition from satisfying needs to fulfilling aspirations, desire and dreams;

- the role of the consumer as an active participant rather than a passive recipient;

- the importance of staff/customer interaction;

- the need for staff to put something of their own personality into their roles;

- the importance of the setting, the design and ambience of the service environment;

- Service delivery as an integrated production - in the cinematic rather than the factory sense of the word. Each time the customer encounters the brand they should get the same high-quality experience.

Yet comparatively little research has been carried out into the nature of the experience from the consumers' perspective. Studies into leisure shopping ${ }^{8}$ have concentrated either on the motivations for visiting a 
particular area, the measurement of the visitors' behaviour and expenditure, or quantitative surveys of their satisfaction, which follow the expectancy disconfirmation approach to service quality. These approaches ask respondents to rate a selection of tangible and intangible elements of the service provided, including the reliability, responsiveness, assurance, and empathy shown by the service staff (eg Parasuraman, Zeithaml and Berry's famous SERVQUAL approach ${ }^{9}$ ). The perceived performance is compared to the expectations formed by previous experience and promotional messages.

Such approaches are criticised as being process-orientated, useful in evaluating the attribute-specific operations of the event, but assume that satisfaction is derived from a cognitive evaluation of the process rather than an affective response to the overall outcome. ${ }^{10}$ Arnould and Price question whether consumers really evaluate experiences against well-defined expectations through a summary index of service performance over several attributes. Instead, they suggest, they bring vague expectations of emotional outcomes, and satisfaction emerges over the time frame of the whole event. ${ }^{11}$ This satisfaction is also interpreted within the broader narrative context of the consumer's life.

Fournier and Mick propose 'a more holistic, context-dependent and dynamic process of satisfaction. This process is revealed as a multimodel, multi-modal blend of motivations, cognitions, emotions, and meanings, embedded in sociocultural settings, which transforms during progressive and regressive consumer-product interactions'.$^{12}$ The problem with this prescription is that it requires time-consuming qualitative research using techniques that encourage customers to reflect and articulate what are often personal and emotional responses.

This paper will explore the elements of the visitor experience using as a case study a netnographic study of regular visitors to the Sidmouth Folk Festival internet-message-board discussions of the changes to the 51st Festival in 2005. The threat to the future of the festival and the changes in organisation meant that regular visitors were all consciously evaluating the new format and reflecting on their experience of the festival. This makes their insights particularly rich and useful in exploring the underlying issues. They discussed the festival on a specialist internet website message board 'The Mudcat Cafe'.

This methodology has been termed 'netnography' - ethnographical studies of internet sources. According to Langer and Beckman, ${ }^{13}$ consumers use internet message boards in order to exchange information and advice about topics of shared interest. The opportunity to masquerade and to cover their identities allows them to express attitudes, opinions, and experiences freely. This enables researchers to study these messages in order gain deeper insights into consumption motives, concerns, and experiences. This means that netnography is a suitable methodology for the study of sensitive or personal research topics, enabling the researcher in an unobtrusive and covert way to gain deeper insights into consumers' opinions, motives, and concerns.

The full details of the research and implications from an Event Management perspective are available elsewhere. ${ }^{14}$ This paper will focus 
on the implications for retail and leisure managers wishing to understand and enhance their customers' experiences.

\section{CASE STUDY}

The festival consists of nearly 300 events over eight days - concerts, dances, workshops and music sessions - in and around the Devon seaside resort. Venues include marquees, theatres, halls, hotel and bar rooms as well street events, processions and a craft fair. Major names in the folk world perform in ticket-only concerts but many of the events are informal sing-arounds and music sessions in public bars. Visitors stayed on a festival campsite or in local hotels and guesthouses.

From 1987 to 2004, it was run by Mrs Casey Music, (MCM), a professional music promoter and event management company. In 2004, during the 50th festival, MCM announced that they could no longer afford to underwrite potential losses due to bad weather, and as no additional grants or sponsorship could be obtained, they were unable to go on managing the event. To save the festival, a number of organisations, public, voluntary and private came together at short notice to promote events in the usual first week of August in 2005.

The 'new' format saw changes not only in ownership and funding but also in the way it was run and the way the visitors experienced it. There was no longer an inclusive season ticket to all events. Instead tickets for individual shows were sold on the door or through the overworked local Tourist Office. The lack of subsidy meant that there were no overseas dance teams or stars, leaving essentially a festival of English folk music, with a few Scots and Irish performers.

The main spatial changes was that there was no Arena Showground in the town park, which had been the venue for big open-air concerts, often including overseas dancers and musicians, and for market stalls and mobile catering vans. The late night dance marquee, which had been located out of town near the campsite, was not provided in 2005. As a result, the 2005 festival was located mainly within the town centre and seafront with festival-goers eating and drinking in local cafes, restaurants and bars.

\section{RESEARCH SOURCE}

Reactions to the new style of festival were debated on the message board of The Mudcat Cafe (www.mudcat.org). This is a folk music web site with a forum, which allows people to ask questions or discuss issues relating to folk music. On 31 July 2005, the first day of the festival a thread 'Sidmouth 2005: the verdict' was started by a poster who had just returned from a day there. The topic attracted a range of messages, which provided unprompted and revealing insights into how the respondents evaluated the festival experience. Many of the replies gave short narratives of 'their festival'.

Over the next 11 days, a total of 95 messages were posted by 59 separate names. Forty five were registered members of the Mudcat forum and 15 were shown as Guests. Ten made between two and six postings responding to the debate, while the rest made just one during the period 
monitored. While no demographic details are available through this kind of research, it was possible from comments made to build up a behavioural profile of the respondents. While six admitted they had not been to the festival, and four had only been for part of it, most had attended for the full week, attending concerts and participating in song, music or dance sessions. Seven identified themselves as volunteer stewards, session organisers or concert performers. Thus, the research provides an insight into the committed core of regular customers, but does not cover other segments of the festival market such as casual day visitors or local residents.

\section{ANALYTICAL FRAMEWORK}

The messages were printed out and analysed using a framework shown in Figure 1. Based on Crompton's distinction between push and pull factors in tourist motivation ${ }^{15}$ and Kapferer's prism of brand identity, ${ }^{16}$ it attempts to create a holistic model of the interaction between the management (the brand owners) and the visitor (the brand consumer).

The top level shows the elements of the experience directly controlled by the management and usually covered by satisfaction studies. The Personality is the overall image as designed and marketed, through the design or selection of the setting, the themes, the range of brands (in this case star performers) and the programme of events. In the theatrical metaphor, these are the on-stage elements that are probably the initial attraction for the visitor. The Physical Operations are the arrangements the management makes, or fails to make, to allow the visitor to come and enjoy the visit to the full, for example, parking, access and queuing, payment, information and assistance. In entertainment these would be termed 'front-of-house' elements.

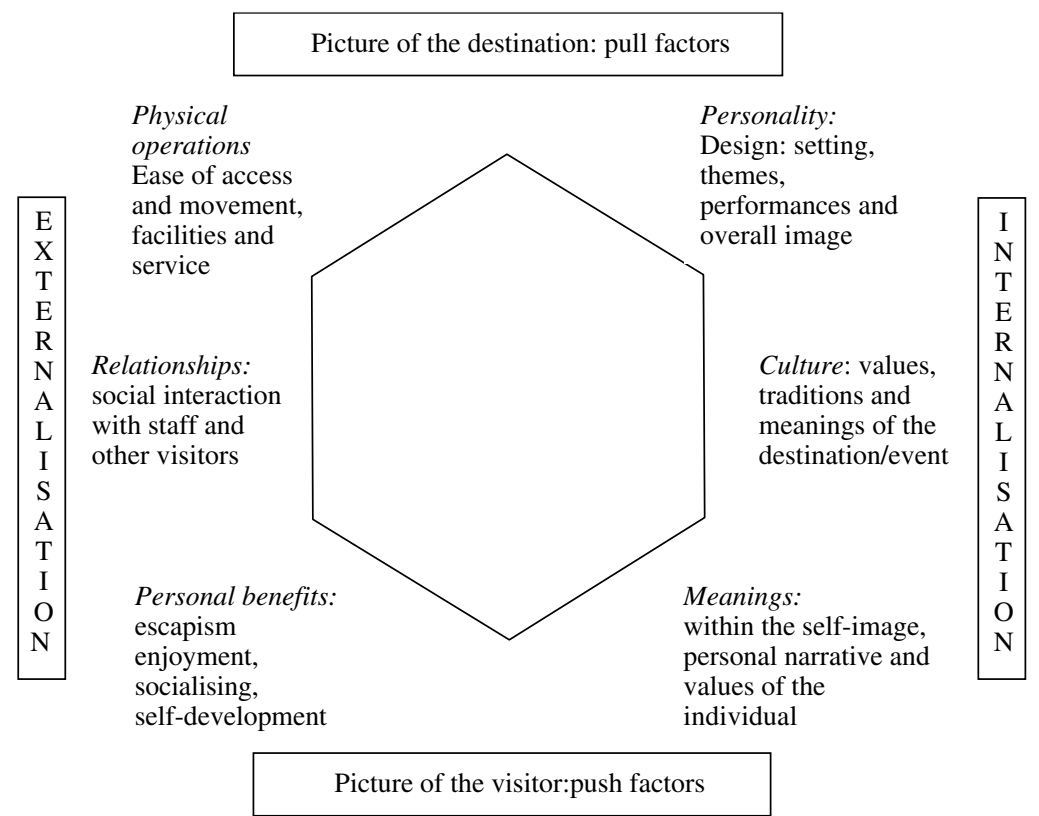

Figure I: The prism of experience (after Kapferer, 1998) 
The bottom level shows the elements that the visitor brings to the experience and usually identified through motivation studies. ${ }^{17}$ These are divided into two 'facets' of the prism. One facet represents the personal benefits and needs they are seeking to satisfy by the visit. However, as well as hedonic pleasures like relaxation, escapism or personal achievement, the visit also has symbolic significance and meanings for the visitor and these were listed separately.

These meanings are 'shaped by their own memories, interests and concerns as much as by their encounter with the attraction'. ${ }^{18}$ In the case of the Sidmouth festival, these were a sense of supporting the continuation of the traditions of the festival and the music, and a concern for how these appeared to outsiders. Examples from retail might be the supporting of the local community or shopping in an ethical or responsible way, or setting the right example to the children. For others, shopping in certain places could be seen as a celebration and display of personal success, wealth and taste. The meaning is created by the interaction of the visitor's own cultural background and their understanding of the historical and cultural significance of the event or location. ${ }^{19}$ There was a vigorous debate about whether the festival had become too commercialised or too conservative in its approach.

The sides of the prism, therefore, explore how the experience is formed through the interaction of the visitor and the event or destination. The left-hand side covers social interactions both between the visitor and the staff ('cast' in Disney parlance) but also between the visitors themselves. In the Sidmouth research, it was the meeting of old and new friends, which was the most frequently mentioned reason why they had enjoyed the festival. The right-hand side covers the interaction between the cultural values of the event organisation and those of the visitor. As discussed in the previous paragraph, the visitor will feel a more positive experience if they approve of what the event or destination stands for.

\section{FINDINGS AND IMPLICATIONS}

The analysis produced long lists of different elements of the event experience commented on in the 95 messages, but these will not be detailed in this paper. What is more interesting for readers of this journal are the lessons for leisure and retail provision generally.

One of the most significant, perhaps, is the interconnectiveness that this qualitative approach reveals. While there were plenty of comments on aspects of the physical organisation and the operational management of the festival, they were not made in isolation. Comments about ticket availability and validity, location and scheduling of events, seating and timekeeping were all made in terms of their effect on the ability of the visitor to move about the festival from event to event. In other words, dissatisfaction did not arise because an aspect of service fell short of expectations, but because it interfered with their underlying aim of making the most of their day. In similar ways, when a visitor to a leisure venue like a club or a tourist attraction complains about parking, queues or cloakroom facilities, what they are really saying is they wanted more time to enjoy themselves unencumbered by outdoor clothing or baggage. 
In the case of a music festival, this aim is to optimise their choice of the experiences on offer. A season ticket allows 'freedom to roam', which leads to unexpected surprises, 'moments of amazement' when they discover a new song, performer or whole genre of music. In this the festival experience could be considered a kind of shopping. In both, the advertised attraction - the headline acts, the sale bargains, the exclusive brands - are only the initial stimulus. As one respondent said, you need them 'to attract ordinary people'. The real excitement, especially for the regular customer, comes from discovering something new for yourself.

This illustrates the interactive nature of experiences. The visitors are not a passive audience for the performances staged by the management, they are part of the performance. This is obviously true of a folk festival where participation in workshops, pub sessions and sing-arounds was mentioned more often than attendance at the formal concerts. It is also true of many sporting occasions, where the costumes, pre- and post-match gatherings, and crowd singing can sometimes be more memorable than what happens on the pitch. These 'fringe' activities are the real experience.

Part of the enjoyment comes from the intensity of effort put in. Arriving late, staying up all night, drinking too much or catching a cold from hugging too many friends become part of the story of the trip. Respondents also recounted proudly their achievements or those of their offspring - songs sung, tunes or dances learnt, prizes won.

These benefits are realised in a social context. Socialising was the aspect of the festival that created the greatest amount of comment on the message boards. The festival was important as an opportunity to meet old friends, make new ones and to share experiences with the family. This confirms previous research ${ }^{20}$ highlighting the importance of socialising as a motive to attend events and other leisure experiences.

What is noteworthy for readers of this journal is that these social exchanges took place in the bars, cafes and restaurants of the town rather than in the main venues. The availability of these facilities provided the impetus for much of the spending, which brings economic benefits to the town. The opportunities for eating and drinking were frequently mentioned in the messages, but again not in isolation. Visitors wanted to be able to eat when it fitted into their plans for the day. Delays in being served because local cafes could not cope with the extra demand meant that people missed the start of the next concert. There was also a shortage of places to eat late and no "convenient late night place where people can wind-down and meet at the end of the day'. Thus, it is the overall blend of retail and leisure provision that retains visitors in the area once they have been to the main attraction or event.

When the respondents tried to sum up the overall experience, they turned to images of the place itself:

'The sessions in the bars, the lovely local beers, the whole atmosphere. We went to some concerts, saw some dancing, sat in the gardens, and walked on the cliffs'.

The setting, in this case, the natural setting and the townscape, become the visual symbol of the experience, while the place name becomes the 
'brand'. 'That's what makes Sidmouth magic' refers to the place the festival and the experience all inextricably entwined in the memory. This emphasises the importance of the visual and sensory environment in leisure and retail. This environment should also include the food and drink. As the quotation above suggests, local food and local drink helps to reinforce the uniqueness and memorability of the experience.

Finally, as discussed earlier, visitors interpreted their experience and evaluated the festival in the light of their own values and concerns, which they used to pass judgment on the values communicated by the event management. The issues debated included authenticity $v$ commercialisation, the survival of the tradition, nostalgia $v$ relevance, and how the festival and the music could reach the younger generation and people from other ethnic traditions. Leisure and retail providers should take account of this 'interpretative' element of experience and ensure that their products and facilities communicate positive brand values in tune with their customers' moral/ethical values and sense of cultural identity. Visitors should feel good rather than uncomfortable about what the place stands for.

\section{CONCLUSIONS AND RECOMMENDATIONS}

This research into customers' leisure experiences has implications beyond the specific area of events. The issues raised in this paper could equally apply to shopping trips or outings to a sporting event or a tourist attraction. Key lessons for planners, marketers and managers are that positive, unique and memorable experiences are likely to come from.

\section{Abundant choice}

People enjoy the freedom to choose from an abundance of offers, even if it is more than they could possibly see or do in the time available.

\section{Moments of amazement}

While most people come with a specific aim to see or buy, they get greater pleasure in discovering something new in the process.

\section{Shared experiences}

The main event is often only the pretext for the real purpose, which is to enjoy the company of friends. This can take place in public spaces or cafes, bars and restaurants away from the main venue. Places to meet before and celebrate or chill-out afterwards are vital to the experience.

\section{The fringe at the heart}

These moments of amazement and these social interactions are as likely to be found in informal fringe events as in the main attraction.

\section{Local distinctiveness}

The landscape and townscapes, the local food and drink can become the sensory cues associated with the experiences, which give the event or location its distinctive and memorable appeal. 


\section{Positive values}

People like to feel that their activities are worthwhile and that they are supporting brands or companies that share their values.

The challenge to retail and leisure organisations is to design these elements of a memorable experience into their offerings, whether in individual facilities, leisure and retail complexes or whole urban centres. Another lesson is to remember that customers evaluate their experiences not through a checklist of individual attributes and service dimensions but as a whole. Qualitative as well as quantitative research is needed as the basis of good design and planning.

\section{References}

1. Pine, B.J. \& Gilmore, J.H. (1999). The Experience Economy: Work is Theatre and Every Business is a Stage, Harvard Business School Press, Boston, USA.

2. UK International Passenger Survey data in Travel Trends (2004), Office of National Statistics London, available at http://www.statistics.gov.uk/downloads/theme_transport/traveltrends2004. pdf. Accessed 31st July 2006.

3. Allport, D. (2005). The UK high street: current issues and their implications. Journal of Retail and Leisure Property 5 (1), 2-16.

4. Grove, S.J., Fisk, R.P. \& Bitner, M.-J. (1992). Dramatizing the service experience: a managerial approach, in Swartz, T. Brown, $\mathrm{S}$ and Bowen (eds) Advances in Services Marketing and Management 1, 91-121.

5. Schmitt, B. H. (1999) Experiential Marketing: How to Get Customers to Sense, Feel, Think, Act, and Relate to Your Company and Brands, Free Press, New York.

6. Jensen, R. (1999) The Dream Society, McGraw-Hill, London.

7. Nijs, D. (2003). Imagineering: engineering for imagination in the emotion economy, in Peeters, P., Schouten, S. \& Nijs D. (ed.), Creating a Fascinating World, NHTV Breda University, The Netherlands.

8. Moscardo, G. (2004). Shopping as a destination attraction: An empirical examination of the role of shopping in tourists' destination choice and experience. Journal of Vacation Marketing 10 (4), 294-307.

9. Parasuraman, A., Zeithaml, V.A. \& Berry, I.L. (1988). SERVQUAL: a multiple item scale for measuring consumer perceptions of service quality. Journal of Retailing 64 (1), 12-40.

10. Buttle, F. (1996). SERVQUAL: review, critique, research agenda. European Journal of Marketing 30, 8-32.

11. Arnould, E.J. \& Price, L.L. (1993). River magic: extraordinary experience and the extended service encounter. Journal of Consumer Research 20 (June), 24-35.

12. Fournier, S. \& Mick, D.G. (1999). Rediscovering satisfaction. Journal of Marketing 63, (October), 5-23.

13. Langer, R., \& Beckman, S. (2005). Sensitive research topics: netnography revereted. Qualitative Market Research 8, (2), 189-203.

14. Morgan, M.E. (2006). What makes a good festival? Understanding the visitor experience. Paper to The Association of Event Management Educators Forum, Bournemouth, June 2006. Accepted for publication Event Management.

15. Crompton, J. (1979). Motivation for pleasure vacations. Journal of Tourism Research 6 (4), 408-429.

16. Kapferer, J.-N. (1998) Strategic Brand Management, Kogan Page, London.

17. Mason, P. \& Beaumont-Kerridge, J. (2004). Motivations for attendance at the 2001 Sidmouth International Festival: fun, family, friends, fulfilment or folk? in Long, P. \& Robinson, M. (eds), Festivals and Tourism: Marketing, Management and Evaluation, Business Education Publishers, Sunderland, UK.

18. Voase, R. (2002). Rediscovering the imagination: investigating active and passive visitor experience in the 21st century. International Journal of Tourism Research 4 (5), 391-399.

19. Chhetri, P., Arrowsmith, C. \& Jackson, M. (2004). Determining hiking experiences in nature based tourism destinations. Tourism Management 25 (1), 31-43.

20. Kim, K., Uysal, M. \& Chen, J.S. (2001). Festival visitor motivation from the organizers' points of view. Event Management 7 (2), 127-134. 